\title{
Globalization and Islamophobia: Critical View at Globalization's Impact on Expansion of Islamophobia
}

\author{
Ahmadreza Bordbar ${ }^{1}$, Shoayb Mohammadi ${ }^{2}$, Pooyesh Parashi $^{3} \&$ Vladyslav Butenko ${ }^{4}$ \\ ${ }^{1}$ Department of Political Science, Kharazmi University, Tehran, Iran \\ ${ }^{2}$ Department of Comparative Politics, Peoples' Friendship University of Russia (RUDN University), Moscow, Russia \\ ${ }^{3}$ Department of Political Science, Kharazmi University, Tehran, Iran \\ ${ }^{4}$ Department of Comparative Politics, Peoples' Friendship University of Russia (RUDN University), Moscow, Russia \\ Correspondence: Ahmadreza Bordbar, Department of Political Science, Kharazmi University, Tehran, Iran. E-mail: \\ bordbar@khu.ac.ir
}

Received: July 27, 2020

Accepted: September 29, 2020

Online Published: October 13, 2020

doi:10.5539/jpl.v13n4p72

URL: https://doi.org/10.5539/jpl.v13n4p72

\begin{abstract}
The globalization process, with its own special tools, is affecting the surrounding world, and the religion of Islam and its ideological structures, as well as any other stream of globalization process, are affected. The process of globalization affected by the current trend is in the pursuit of dominance over other competing ideologies and, in the meantime, deals with the struggle with competing ideologies with tools such as the spread of democracy, technology, consumerism, and so on. The process of globalization in dealing with Islamic ideology, due to structural, fundamental, ideological and so on contradictions, reveals the ideology of political Islam as weak and weak. The globalization discourse with the central point of modernism opposes other discourses and is now struggling with the discourse of political Islam. Globalization discourse, with its special system of meaning, seeks to change the values of the political Islam discourse. One of the most striking features of globalization discourse is through the political Islam discourse, the concentration and expansion of the idea of Islamophobia. The idea of Islamophobia is one of the socio-political foundations of the domination system, which has emerged through the mechanisms of the globalization process. In this research, the data have been gathered using the documentary methodology, the theoretical framework of the research has shaped theories of the critical school and postmodern thought, and the analysis of the research data has been done using the method of critical discourse analysis.
\end{abstract}

Keywords: discourse, globalization, Islamophobia, meaning

\section{Introduction}

The idea of Islamophobia brings with it the importance of changing the values of the ideology of political Islam. The emphasis and focus of the domination system on such issues as the spread of Islamic terrorism, the confrontation of Islamic culture with Western culture, the dualism of the Islamic world and the Western world, consumerism Islam and so on all are examples of the expansion of the ideology and flow of Islamophobia in the present era. The emergence of a major wave of Islamophobia in societies with a different biology and worldview of Islamic biology and Islamic worldview has nothing to do with the opposition and rejection of political Islam discourse. Hence, in the present era, what represents the name of Islam, Islamism, being Muslim, and so on is more closely tied up with phenomena such as terrorism, extremism, and so on.

The value of showing the indices of globalization discourse against other discourses and attempting to follow the path of globalization as the only path to social happiness of societies is not an objective other than cultural, political, social, economic, etc., to other societies with its own discourses. This path of discourse in the process of globalization has become more visible against the political Islam discourse and has increased the level of conflict in the current era.

In light of the foregoing, the fundamental question of this research is how did the globalization process foster the spread of the idea of Islamophobia? In response to this question, the research hypothesis is that the globalization process, using tools such as the emphasis on the development of the ideals of modernism, consumer societies, democratic structures, human rights, unpromising media and so on follows a sharp contrast to the ideology of political Islam. And in this way, it spreads the idea of Islamophobia. In fact, the idea of Islamophobia is the rational 
outcome of the process of globalization in the target countries and societies.

Whether any society has its own discourse and that it is about that value-driven discourse is obvious; the main issue is the discourse's attitude and the attempt to eliminate it. The globalization process, like any other phenomenon or idea, has its own discourse, but the instrumentation of this discourse in the system of domination and its attempt to overcome other discourses in the general sense and the political Islam discourse in a certain sense has led to several problems.

A brief view at the main debates in the media over the past few years can be easily understood that the discursive attitude of capitalism's domination and hegemony has been the most discursive political Islam discourse. The hegemony of the capitalist system has always benefited from the globalization discourse as a means of confronting the political Islam discourse and its weakening, and dally explicitly claims that the creation of the keyword "Islamophobia" in western literature.

Globalization discourse, with the emphasis on Islamophobia metanarrative, is attempting to marginalize any narrative or other narrative that exists or can be created from the political Islam discourse, and formed its metanarrative which is based on the socio-political construct. Then, this discourse will dominate.

One of the most effective ways in which the system of domination uses the globalization discourse in this way, is media control; in fact, as one of the most important means of globalization is the phenomenon of media, the domination system also creates propaganda and media stimulation. Describes a phenomenon that Jean Baudrillard mentions to be hyperreality. The domination system, by magnifying and displaying the desired pieces of reality, gives rise to a new, incoherent and fragmented reality, transforming it into a transcendence through media control and guidance. The idea of islamophobia, using such a mechanism of phenomena, came and is expanding.

\section{Theoretical and Historical Literature}

As stated, the theoretical framework of this research has shaped the critical theories of the Frankfurt School and postmodern thought. In the case of Frankfurt School, this school is associated with the theory of criticism, the German school name established in the 1930s by Max Horkheimer in the form of a community research association in the city of Frankfurt (Held, 1980).

From the perspective of the Frankfurt School, the emergence and expansion of the mass media and the culture industry, as well as the unceasing breach of their lives in the twentieth century, reflects the rotation of the nineteenth-century self-regulating liberal capitalism into organized and planned capitalism of the twentieth century (Adorno \& Horkheimer, 2002).

The flow of postmodernism also refers to the widespread developments in the critical attitude, philosophy, architecture, art, literature, and culture, which came from the core of the modernist movement, in response to it, or as its successor. Postmodernism is a historical-sociological concept that incorporates the postmodern era's historical period. The turning of postmodernism from the repressive reign of proximity to the autonomy of the penetrating circle is defined. Also, postmodernism is another modernity that contemplates modernity with a new look and adopts the critical and critical tradition of modernity about its own modernity (Connor, 1987).

The emergence of postmodernism has been attributed to a range of factors, including: the loss of faith in rational explanations, the decline in the importance and centrality of labor in everyday life, and the emergence of a postindustrial society based on consumerism and leisure. The growing power of the media is to turn the vast array of images and texts among the global audience (Kellner, 1995).

In the short history of the research, five books in the field of globalization and related subjects, and five books in the field of Islamophobia and related issues are mentioned. In the field of globalization, the following books can be mentioned:

The book "Globalization: Key Thinkers" (2017), written by Andrew Jones, outlines the most important theories of globalization and the views of various thinkers about this process. The book "Sociology of Globalization: A Critical Appraisal" (2010), written by Saskia Sassen, has a sociological study of the globalization process. The book, "Manifesto for a New World Order" (2009), written by George Monbiot, presents a new perspective on the process of globalization. The Book "Global Governance" (2014), written by Catherine Lowe, describes politics in the era of global governance. The book "Development as Freedom" (2002), written by Amartya Sen, explores the relationship between development and freedom.

In the field of Islamophobia, can also mention the following books:

The book "American Islamophobia" (2018), written by Khaled Baydoun, examines the policies of the United States of America in creating and expanding the idea of Islamophobia. The book "The Islamophobia Industry" 
(2017), written by Nathan Lean, explores the economic dimensions and benefits that extend the idea of Islamophobia to Western governments. The book "Islamophobia" (2016), written by Deepa Kumar, addresses the specific issue of Islamophobia in the United States of America. The book "Islamophobia" (2010), written by Chris Allen, examines the ways of coping and the recognition of the idea of Islamophobia. The book "Multiculturalism or Islamophobia?" (2014), by Rezq Farouq, explores the relationship between culture and Islamophobia.

It should also be said that there are other tremendous books that, due to the abbreviations, were refused their expression, and only the above mentioned examples became obsolete.

\section{Methodology}

As stated, the method for collecting data in this research is the documentary method. As for the documentary method, it should be said that, in the book "An Introduction to Qualitative Research", Uwe Flick states: "When you decide to use documents in your research, you should always look at them in the face of communication tools. Also, you should ask yourself who this document was for, for what and from whom?" (Flick, 2009).

Documentary research is evidence - based research based on the study of documents (Khaledi, 2014).

In the words of Michel Foucault: "The document is not a fortune-telling tool of history, a history of itself and of all, of memory; history is a way for a community to dignify and treat it to a bunch of documents that history does not separate (Foucault, 2017).

Documentary research method is considered as a complete and technical way to strengthen other qualitative methods in social science research. In this way, the researcher collects his data from sources and documents, and a significant part of the theoretical research in the sociology field uses the documentary method, whether it is desired or unwanted (Sadeghi Fasaiee \& Erfanmanesh, 2015).

The documentary method was coherent with the sociology of knowledge of Karl Mannheim (Mostakhdemin Hosseini, 2015).

This method has also been very much borne out by the phenomenological methods of the community, the school of Chicago, and so on. The documentary method is widely used in analyzing group decisions and narrative interviews and many other researches (Weller \& Malheiros da Silva, 2011).

The method of analyzing data is also a critical discourse analysis method. Regarding this methodology, critical discourse analysis was first introduced by Norman Fairclough. This tendency in the twentieth century, following the change in the social sciences, came up with the advent of theories of Karl Marx, Antonio Gramsci, Louis Althusser, Jurgen Habermas, Michel Foucault, Pierre Bourdieu and ... to investigate the misuse of the notion of intimacy, injustice and inequality resulting from it became pervasive. Discourse analysis was also important in identifying the meaning of a text, in addition to the constituent elements of the sentence and the context of the text, external factors such as social, cultural, political, and so on (Saraiee et al., 2008).

The discourse of critical language discourse is considered as a social and political action; discourse is involved in creating social behaviors, magnifying and distorting identities, and how social discourse changes and sustains social processes. In the analysis of critical discourse, language alone is not the birth of social and political relations, but is itself contributing to the formation of a social and pro-social interest (Laclau et al., 2016).

Critical discourse analysis is a cross - media approach to the study of discourse (Soltani, 2005).

Language in this way is a form of social action in relation to the community and its non-sexual context (Aghagolzadeh, 2006).

Discourse focuses on shaping social practices, magnifying and distorting identities, and how it contributes to the transformation and continuity of social processes. Critical discourse analysis seeks to reveal hidden ideologies behind texts and speeches and seek to resist social inequalities. Jürgen Habermas states that language is a tool of domination and social power and serves to legitimize the power relations (Aghagolzadeh \& Dehghan, 2015).

\section{Results and Discussion}

\subsection{Globalization Discourse and the Point of Modernism}

Globalization is the process of interaction and the integration of people, companies and governments around the world. Globalization has expanded due to the advances in communication and transportation technology (AlHemadi, 2002).

Increasing global reciprocity, growth of business, ideas and international culture. Globalization in the first place is an economic process as an economic interaction that is associated with cultural and social aspects. Nevertheless, conflict and diplomacy have always been part of the history of globalization - especially modern globalization 
(Zirak, 2018).

Based on some perspectives consistent with the process of globalization, this event can lead to the development of links and interconnections beyond states, and bring the importance of localism and ethnicity to its lowest (Jenani \& Ziyaieefar, 2006).

In the context of globalization, the relationship between culture and technology in the context of any analysis of the concept of power will be make and the concept of power, is a basic concept in this analysis (Kiyani, 2001).

The point of Modernism, as the central point and points such as culture, technology and... as floating points, play a crucial role in shaping the discursive hegemony of the globalization process; in fact, globalization discourse, using the ideals of the modernist trend, tries to articulating its cultural elements and operating its cultural hegemony (Buy, 2013).

But in order to the relation between globalization discourse and political Islam discourse, political Islam discourse is more consistent with the technological approach of the globalization process than with its ideological approach, since the Islamic religion conflicts with the ideological perspective in various aspects of globalization discourse (Sajjadi, 2010).

One of the reasons for the conflict of political Islam discourse with the globalization discourse is that all cultures and societies do not have equal access to modern technologies and do not play an effective role in the process of formulation and realization; hence from a technical point of view, secular systems are superior to Muslims. Islam religion is not in conflict with the technical and hardware dimension of the globalization process, unless technology is indissolubly interpreted from the culture and ideology of the ruling Western world, which proves such a claim is not so easy. But in any case, there is no doubt that Islam religion is inevitably faced with the aspects of software and cultural content and the political - economic consequences of the Western world (globalization based on Western foundations, patterns, definition, meaning and so on) (Nekoiee Samani, 2008).

One of the reasons for the strengthening and coherence of Islamic fundamentalism in the present era is the issue that Muslims insist on maintaining their Islamic identity and seek to reproduce themselves, following the danger of being removed. Another aspect that leads to the challenge of the political Islam discourse with the discourse of globalization is that religious teachings, religious values, and ethical standards of the Islamic faith are absolute, fixed and invisible, while the process of globalization. The present is not based on any sacred and divine values, and if it does not negate these values, at least they are not accepted. Hence, values, beliefs, and religious system are not compatible with relativism, pluralism and cultural influence of globalization discourse, and in many cases, they are against them. Ernest Gellner states (1992): “Among the claims that Western doctrines are globalized, inclusive and covering the whole world, there is an inconsistency with Islamic teachings, and this incongruity causes both to negate one another". And Islamic fundamentalism seeks to reproduce itself following the danger of the removal of the Islamic identity, and this incompatibility is increasing day by day.

\subsection{Islamophobia Discourse and the Point of Terrorism}

Islamophobia means an unnecessary and groundless culture of fear against Muslims and Islam religion. Namely, Islamophobia term may be defined sociologically as the fear that the Western society has against Muslims. That fear which subconsciously ingrained in Westerners was formed first time in the areas in Asia Minor called as "frontier" where Muslim and European Christian armies confront during the Crusades. The idea of islamophobia makes fear, hatred, or discrimination against Islam religion or Muslims, and includes a kind of racism. A group in the British Parliament in 2018 defined the idea of Islamophobia as follows: "Islamophobia is rooted in racism and is aimed at targeting actual or special manifestations of being Muslim". The background dates back to the 1980s, but after the attacks of September 11, 2001, it became much more widely used (Fredman, 2001).

The Runnymede Trust Institute in the United Kingdom, which studies discrimination and hatred in the country, in 1997, defined the phenomenon of Islamophobia as a fear and hatred of Islam, and therefore fear and hatred of all Muslims. This term implies the discrimination and exclusion of Muslims from economic, social and public life in countries as well. Also, the idea of Islamophobia implies that the religion of Islam lacks the common value of other cultures, compared to Western culture in a subordinate position, and is more of a political ideology than religion ('Islamophobia: A Challenge for Us All', 1997).

There are a number of other terms used to refer to negative feelings and attitudes towards Islam and Muslims, such as anti-Islamism, intolerance of Muslims, anti-Islamic prejudice, hatred of Muslims, anti-Islamism, Muslim phobia, and the demonic nature of Islam and Muslims. In Germany, the terms Islamophobia (fear) and anti-Islamism (hostility) are used. In Scandinavia, the word is used to mean hatred of Muslims (Kaya, 2014).

In fact, in the term of Islamophobia, Muslims are considered as individuals or groups that are opposed to the values 
of Western discourse, and as enemies and threats to these values, as well as their national coherence. This term refers to the (irrational) and anti-Islamic anti-Semitism (Islam religion) of Muslims that can be analyzed in various areas of discourse, such as political, economic, cultural, etc. (Nakhaiee, 2011).

In a general outline, the main features of the discourse of Islamophobia can be summarized as follows: a static and unchanging look at the religion of Islam; the view of Islam as a kind of ideology that does not have common values with other cultures does not affect them and does not affect them; the view that the discourse of Islamic politics sees below Western discourse and regards it as violent, irrational, primitive, and gendered; the view that Islam is violent, aggressive, threatening, supportive of the phenomenon of terrorism and involved in the battle of civilizations; a view that sees the religion of Islam as a political ideology used to gain political or military superiority, and also to reject the immediate discovery of any criticism that Muslims have of the "Western discourse"; following such characteristics, hostility to the religion of Islam to justify acts Discriminatory against Muslims and separating them from the body of society, the hostility of anti-muslims is natural and normal ('AllParty Parliamentary Group on British Muslims', 2019).

One of the reasons for the formation and intensification of Islamophobia discourse in the present era is the emergence of the ideology of political Islam. In the present era, various Islamic trends have emphasized the political dimensions of the Islamic religion. The propaganda efforts of these currents in various countries, especially since the 1970s, have had a great influence on the philosophy of Islamophobia. Meanwhile, Salafist currents, with the support of governments such as the Saudi government, have propagandized propaganda to expand their views. The enormous financial resources and extensive media outlets of these currents have led the people of non-Muslim countries to formulate their own ideas based on the reading of these currents from the religion of Islam. Also, the other aspect of the influence of the ideology of political Islam on the formation of the Islamophobia discourse can be seen in the formation of extremist political organizations and groups such as the "Muslim community", "Al-Takfir", "Al-Jahrah", "Al-Jihad", "Al-Qaeda" and so on (Morshegizad \& Ghaffari Hashjin, 2007).

\subsection{Discourse Interaction or Opposition?}

Globalization discourse has influenced the ideology of Islam in many ways, and in general terms it can be argued that the discourse of Islamophobia on the discursive opposition of these two facts has been indisputable. For example, one can have a very brief look at Islamic extremist movements. From the perspective of one of the thinkers of the critical school, Slavoj Žižek, Islamic extremism is a "charming" reaction to the flow of liberalism and its manifestations elsewhere in the world (Žižek, 2015).

Today, the anti-globalization discourse acts as a feed for radical Islamists movements, because marginalized and displaced spaces are occupied by a large population of Muslims. In fact, returning to the religion of Islam for these people has created a protesting and aggressive identity, basically with such a new identity that Muslim extremists are redefining and expanding the struggle between globalization discourse and political discourse. In such a situation, the philosophy of Islamophobia is becoming more and more abundant (Roy, 2008).

Extremism in every ritual in a general way and in the religion of Islam in a particular way, such as a general and conservative tendency, a rebellion against the ideals and thoughts of modernity, and also an enlightened Western heritage. Extremists in all religions are trying to rise with absolute explanations to confront modernist relativism. Extremism has been against the principles of the current of modernity, namely, principles such as individualism, rationalism, universalism, freedom, tolerance, democracy, pluralism, humanism, relativism, and, on the contrary, have supported absolute and unchangeable values. For example, this description is also used to describe the European migration crisis. Such an attitude and approach to the religion of Islam has essentially led to the formation of the Islamophobia discourse in the present era (Javane Shahraki, 2008).

Another aspect of the impact of globalization discourse on the creation and expansion of the Islamophobic discourse can be seen in the formation of consumer societies. From postmodern Jean Baudrillard's point of view, consumer society, by virtue of the myth of happiness, creates the concept of need in a superficial way, in order to justify the encouragement of people to consume more. In fact, the consumption of goods is a catalyst for social gaps and a hierarchy of major discriminations in the field of power. From Baudrillard's point of view, the myth of happiness, since it embodies the idea of equality in modern societies, has the ability to be the starting point for mediating the consumer society in achieving individual salvation by meeting individual needs. But the happiness myth, in order to be a worthy representative of the idea of equality, must first be measured: "Well-being must be measured through objects, signs, and comfort. Such a need can simply be false to the Arab countries of the Middle East for the sale of military weapons from the United States on the one hand, and the creation of a false intimidation of the emergence of Islam terrorism, as well as the creation of an Islamophobic discourse in the world from the 
hegemon of the domination system" (Baudrillard, 2010).

Another instrument of globalization discourse is to create a dialogue of Islamophobia, overuse and much controlled by the media, in this study, the concept of media, all its types, including television, cinema, music, the Internet, books, magazines, etc. takes the hegemony of the domination system, through the use of the globalization discourse and the media tool, to create false demands, to showcase the globalization discourse, to reproduce the ruling ideology, to create proxies, etc., has simply expanded the discourse of Islamophobia, Islamic terrorism, and extremist Islam, and It plays a role in shaping global public opinion; while the United States' largest allies in the Middle East are Islamic countries like Saudi Arabia, which are themselves the most fundamentalist countries (Chomsky, 2007).

Another example of the use of media for expanding the discourse of Islamophobia from the hegemon of the domineering system can be seen in American textbooks. The perception of the people of the United States of America of Islam religion and the Middle East originates high school textbooks, with only three percent of the books on the history of the world dedicated to these two categories, the Middle East and the Islamic religion. In Middle Eastern history books, it was written that the Middle Asia in the Middle Ages had a brilliant civilization, but was sunk in turmoil, repression and violence due to its inability to adapt itself to the modern world. Also, these books refer to Arabs and Muslims as humiliating and alienated. The promotion of Islamophobia discourse in the United States of America has caused the most horrible crimes against Arabs and Muslims in the country, for example, in 2016, the number of attacks and conflicts rooted in anger and hatred towards Muslims, Arabs and Hijab in the United states of America, increased even more than since the onset of the attacks on September 11, 2001 (Levinson, 2018).

Using media to expand the goals of the domination system and create hyperreality, Jean Baudrillard has shown goodness in the article "Gulf War Did Not Take Place". He states that when such a war broke out, many went to the television to get information about it, and they expected the television to give them news and information, but the television network $\mathrm{CNN}$, in a live report with his correspondent, he calls for the latest developments on the front of the war, and it is interesting that the correspondent has been put on television and he reports the incident on the images he sees on television. What does this mean? That is, not the reality, but the image based on the reality of the report of the reporters of the television network CNN it has been. Baudrillard (1995) states that, reporting according to television and such medias reports, are essentially surreal. That means, people can't believe them in the first view.

Edward Said (2000) also states: The American and Western media outlets and experts determine what the human mind looks to other parts of the world (the others), and that, instead of the academic debate on the religion of Islam, only the journalists saw the news Handle it, re-envelop it and publish it in its media. Edward Said, the Dean of Islam, considers the media to be one-sided act that shows that what Arabs and Muslims do is at the highest level of intrinsic defects and that they are afraid of the religion of Islam through the medium of media.

In fact, Islamophobia discourse is a sort of management of perceptions that is more than the media. According to Neil Postman (1984), "the man does not see reality as it is, but sees how his languages speak, and his languages are the media". Postman thought that the way television works makes certain societal conversations impossible and reshapes others to the point of triviality by turning everything into entertainment. Since television is image-based, biased toward attention-grabbing images presented in quick succession, and presents information often out of context and in random order, it is impossible to have a logical, language-based, coherent discussion about anything.

Another indication of globalization is to focus on the extension of the concept of democracy and human rights in other countries. The new world order of President George W. Bush, introduced by pre-emptive warfare and whose content was intended to extend the concepts of democracy and human rights, came with imperial goals from which there were groups such as ISIL, Boko Haram and thousands of other terrorist streams (Najafi, 2016).

Karl Schmitt (2016) states: "Even with globalization and the spread of late capitalism, there are still governments, and these states, even if weakened, are still decisive and can play a role in the political destiny of the world". This chaffy new world-order, which the American Neocon has given to the world, has not produced a Middle Eastern region other than the development of postmodern nihilism (Farhadpoor, 2016).

Many of the current debates in the West about Islamism are related to its political identity and less on the foundations of ontology, sociology and theory of Islamic knowledge. This is partly due to the efforts made by Islamists to revive Islamic thought in relation to modern Islamic political movements (Boggs, 1986).

In other words, Islamism as a political ideology, in spite of some agreements and commonalities, is distinct from traditional Islam as a "religion" and a "cultural concept". Hence, Islam is considered as a "meaningful 
transcendental sign" in Islamic societies and the only point of symbolic authority for unification and meaning. It sees, Islam not only as a superior signifier for the establishment of political order, but also as an identifying element through which Muslims introduce and realize themselves. In other words, when Islam becomes Islamism, it somehow reconsiders its legitimizing foundations in order to gain a foothold and move out of the margins to participate in the process of world history. In this sense, Islam seeks to free itself from the shackles of traditional values and interpretations, reviewing the concepts and their easy use in order to mobilize and equip Muslims, can do a kind of confrontation with new ideologies (Yazbeck Haddad, 2003).

In fact, one of the most important global challenges of Islam is to portray the fear of Islam and Muslims. American companies have the biggest role to play in managing mass media and dominating communication technologies. Presenting a frightening image of Islam that shows Muslims as backward, violent, ruthless, disregarding human rights, violating women's rights, etc. is the biggest challenge of this religion in the world today. These images have led to the deprivation of Western Muslims of their citizenship rights, and have led Western public opinion in the West to increasingly accept restrictions on Muslims and to treat them. It can certainly be said that the image of terror of Islam and Muslims has become more prevalent after September 11 attacks and the destruction of the Twin Towers. The events of September 11 attacks led to a kind of association of meanings and turned doubts into an institutional belief in Western public opinion that Muslims are truly violent and belligerent (A'meli, 2003).

\section{Conclusion}

If the globalization discourse is viewed as the domination of domination, supreme culture, superior system, and interpretations of this kind, then the ground for discursive opposition is provided. If a discourse does not allow the growth and prosperity of other discourses or even rivals, there is no room left for dialogue and engagement. For the most part, globalization discourse in modern times seeks to eliminate rival discourses, especially the political discourse of Islam, and basically, such an approach is not compatible with the initial ideals of modernity or globalization.

The hegemony of the domination system, through the emphasis on the central slab and the floating globalization discourse, has been able to create a new discourse; a discourse that, contrary to other currents, is a reminder of fear and fear of the religion of Islam. A discourse that is considered in complete opposition to the universal discourse, as if it were seeking to destroy it, and there is no way for a compromise or dialogue between them.

Finally, the authors' goal in this research was not to support any dominant discourse, but all attempts were made to review the discourse with an academic look. The hegemony of the domination system through the platforms of globalization discourse, the signs, the media control, the creation of a consumer society, the spread of the ideals of democracy, the shift to the idea of human rights, etc., has, on the one hand, in Muslim communities or even Muslim individuals, has developed its own ideas And, on the other hand, diminishes the general public's view of Islam, Islamism, and Islam, in order to gain the most benefit from this first step, and to stabilize its hegemony in the next step. The system of domination, confronts the religion of Islam in the present day through the spread of Islamophobia discourse. In fact, Islamophobia is a discourse based on the hegemon of the domination system.

\section{References}

A'meli, A. (2003). Globalizations: Westernization and Islamization of the world, Islamophobia and growing modernity, the universality of Islam and globalization. World Assembly for the Approximation of Islamic Religions Journal, 19, 276-322.

Adorno, T. W., \& Horkheimer, M. (2002). Dialectic of enlightenment (E. Jephcott, Trans.). Stanford: Stanford University. https://doi.org/10.1515/9780804788090

Aghagolzadeh, F. (2006). Critical discourse analysis. Tehran: Ney Press.

Aghagolzadeh, F., \& Dehghan, M. (2015). The analysis of news selection representative methods from CDA perspective. Language Linguistic Journal, 5, 66-83.

Al-Hemadi, A. (2002). We and the symbols of globalization (Abdullah Nekouname Ghadimi, Trans.). Hamshahri Journal, 1658, 10-16.

Allen, C. (2010). Islamophobia. London: Routledge Press.

All-party parliamentary group on British Muslims. (2019). London: APPG.

Baudrillard, J. (1995). The Gulf War did not take place (P. Patton, Trans.). Bloomington: Indiana University Press.

Baudrillard, J. (2010). The consumer society: Myths and structures (Parviz Izadi, Trans.). Tehran: Sales Press.

Beydoun, K. (2018). American Islamophobia. California: University of California Press. 
https://doi.org/10.1525/9780520970007

Boggs, C. (1986). Social movements and political power. Philadelphia: Philadelphia U.P.

Buy, A. (2013). The discourse of globalization: Hegemony and the transformation of the global system from geopolitics to geo-culture. Political Studies Journal, 20, 57-81.

Chomsky, N. (2007, April 28). America's war against Islam is transformed into a Third World War. Retrieved from https://basirat.ir/fa/news.

Connor, S. (1987). Postmodern culture: An introduction to theories of the contemporary. Oxford: Blackwell.

Farhadpoor, M. (2016). The new world order of America and the emergence of Al-Qaeda as Postmodern nihilism. Etemad Journal, 2998, 2-9.

Farouq, R. (2014). Multiculturalism or Islamophobia? London: LAP Lambert Academic Press.

Flick, U. (2009). An Introduction to Qualitative Research (Hadi Jalili, Trans.). Tehran: Ney Press.

Foucault, M. (2017). The Archaeology of knowledge (Nikoo Sarkhosh \& Afshin Jahandideh, Trans.). Tehran: Ney Press.

Fredman, S. (2001). Discrimination and human rights. London: Oxford University Press. https://doi.org/10.1093/acprof:oso/9780199246038.001.0001

Gellner, E. (1992). Postmodernism, reason and religion. London: Routledge Press.

Held, D. (1980). Introduction to critical theory: Horkheimer to Habermas. California: University of California Press. https://doi.org/10.1525/9780520341272

Islamophobia: A challenge for us all. (1997). London: Ashgate Press.

Javane Shahraki, M. (2008). The role of globalization in promoting religious fundamentalism: A case study of AlQaeda. Strategy Journal, 47, 117-136.

Jenani, A., \& Ziyaieefar, M. (2006). Davos Summit for globalization and strategies for Iran's globalization. Issues and Economic Policies Journal, 13, 63-90.

Jones, A. (2017). Globalization: Key thinkers (Masoud Karbasiyan \& Hamayak Awrisyans, Trans.). Tehran: Cheshmeh Press.

Kaya, A. (2014). Islamophobia. In J. Cesari (Ed.), The Oxford handbook of European Islam. Oxford: Oxford University Press.

Kellner, D. (1995). Media culture: Cultural studies, identity, and politics between the Modern and the Postmodern. New York, NY: Routledge Press.

Khaledi, S. (2014). Documentary research. In Baqer Al-Uloom Research Institute Website. Retrieved from http://pajoohe.ir

Kiyani, D. (2001). Global culture: Myth or reality? International Studies Journal, 10, 96-113.

Kumar, D. (2016). Islamophobia. Chicago: Haymarket Books Press.

Laclau, E., Mouffe, C., \& Fairclough, N. (2016). Political discourse analysis: The political as a discourse construct (Amir Rezaieepanah, Trans.). Tehran: Tisa Press.

Lean, N. (2017). The Islamophobia industry. London: Pluto Press. https://doi.org/10.2307/j.ctt1v2xvxq

Levinson, M. (2018, August 7). American children are learning islamophobia from their textbooks. Asre Diplomacy Website. Retrieved from https://www.huffpost.com/entry/opinion-levinson-islamophobiamuslims-textbooks.

Lowe K. (2014). Global governance (Mahdi Parsa, Trans.). Tehran: Ghoghnoos Press.

Monbiot, G. (2009). Manifesto for a new world order (Mirmahmood Nabavi, Trans.). Tehran: Cheshmeh Press.

Morshedizad, A., \& Ghaffari Hashjin, Z. (2007). Islamophobia in Europe: Origins and factors. Political Knowledge Journal, 6, 55-83.

Mostakhdemine Hosaini, H. (2015). An introduction to the research method in the humanities. Labor and Society Journal, 187, 239-267.

Najafi, S. (2016). The new world order of America and the emergence of Al-Qaeda as Postmodern nihilism. Etemad Journal, 2998, 3-6. 
Nakhaiee, M. (2011). An introduction to the cause of Islamophobia. Keyhan Farhangi Journal, 2457, 299-300.

Nekooiee Samani, M. (2008). Islam and globalization: Interaction or conflict? Marefat Journal, 133, 69-76.

Postman, N. (1984). Amusing ourselves to death: Public discourse in the age of show business. New York, NY: Penguin Press.

Roy, O. (2008). Globalized Islam (Hasan Farshtiyan, Trans.). Qom: Boostane Ketab Press.

Sadeghi Fasaiee, S., \& Erfanmanesh, I. (2015). Foundations of methodological of the documentary method in Social Sciences. Strategy of Culture Journal, 29, 154-178.

Said, E. (2000). Covering Islam: How the media and the experts determine how we see the rest of the world. New York, NY: Random House Press.

Sajjadi, A. (2010). Islam and globalization. Reflection of Thought Journal, 40, 111-136.

Saraiee, H., Fathi, S., \& Zare, Z. (2008). Qualitative method in Social Studies, with emphasis on discourse analysis method and critical discourse analysis. Social Sciences Journal, 3, 247-268.

Sassen, S. (2010). Sociology of globalization: A critical appraisal (Masoud Karbasiyan, Trans.). Tehran: Cheshmeh Press.

Sen, A. (2002). Development as freedom (Ahmad Movasseghi, Trans.). Tehran: University of Tehran Press.

Soltani, A. (2005). Power, discourse and language. Tehran: Ney Press.

Weller, W., \& Malheiros da Silva, C. (2011). Documentary method and participatory research: Some interfaces. International Journal of Action Research, 7. 294-318.

Yazbeck Haddad, Y. (2003). Islamist perceptions of U.S. policy in the Middle East. In D. W. Lesch (Ed), The Middle East and the United States: Westview, 87, 158-189.

Zirak, M. (2018). Analysis of the outcomes and business gains of globalization, regionalism and Iran's accession to the World Trade Organization. Review of Issues and Economic Policies Journal, 17, 83-84.

Žižek, S. (2015). Blasphemische Gedanken: Islam und Modern. Ullstein.

\section{Copyrights}

Copyright for this article is retained by the author(s), with first publication rights granted to the journal.

This is an open-access article distributed under the terms and conditions of the Creative Commons Attribution license (http://creativecommons.org/licenses/by/4.0/). 